\title{
A survey of entomopathogenic nematode species in continental Portugal
}

\author{
V. Valadas ${ }^{1}$, M. Laranjo ${ }^{2,3}$, M. Mota ${ }^{1}$ and S. Oliveira ${ }^{2 *}$ \\ ${ }^{1}$ NemaLab-ICAAM (Instituto de Ciências Agrárias e Ambientais \\ Meditterrânicas) and Departamento de Biologia, Universidade de Évora, \\ Évora, Portugal: ${ }^{2}$ Lab. Microbiologia do Solo-ICAAM (Instituto de \\ Ciências Agrárias e Ambientais Meditterrânicas) and Departamento de \\ Biologia, Universidade de Évora, Évora, Portugal: \\ ${ }^{3}$ IIFA (Instituto de Investigação e Formação Avançada), Universidade de \\ Evora, Évora, Portugal
}

(Received 23 July 2012; Accepted 11 March 2013)

\begin{abstract}
Entomopathogenic nematodes (EPN) are lethal parasites of insects, used as biocontrol agents. The objectives of this work were to survey the presence of EPN in continental Portugal and to characterize the different species. Of the 791 soil samples collected throughout continental Portugal, 53 were positive for EPN. Steinernema feltiae and Heterorhabditis bacteriophora were the two most abundant species. Analysis of EPN geographical distribution revealed an association between nematode species and vegetation type. Heterorhabditis bacteriophora was mostly found in the Alentejo region while $S$. feltiae was present in land occupied by agriculture with natural vegetation, broadleaved forest, mixed forest and transitional woodland-shrub, agro-forestry areas, complex cultivated patterns and non-irrigated arable land. Although no clear association was found between species and soil type, S. feltiae was typically recovered from cambisols and $H$. bacteriophora was more abundant in lithosols. Sequencing of the internal transcribed spacer (ITS) region indicated that $S$. feltiae was the most abundant species, followed by H. bacteriophora. Steinernema intermedium and S. kraussei were each isolated from one site and Steinernema sp. from two sites. Phylogenetic analyses of ITS, D2D3 expansion region of the 28S rRNA gene, as well as mitochondrial cytochrome $c$ oxidase subunit I (COXI) and cytochrome $b(c y t b)$ genes, was performed to evaluate the genetic diversity of $S$. feltiae and H. bacteriophora. No significant genetic diversity was found among $H$. bacteriophora isolates. However, COXI seems to be the best marker to study genetic diversity of S. feltiae. This survey contributes to the understanding of EPN distribution in Europe.
\end{abstract}

\section{Introduction}

Entomopathogenic nematodes (EPN) are a group of nematode families which are insect parasites and possess many attributes that enable their commercial use as biocontrol agents (Kaya \& Stock, 1997). They are promising candidates for biocontrol of insects due to their ability to search for hosts, safety to non-target

*E-mail: ismo@uevora.pt organisms and the environment, high reproductive potential, capacity to be mass produced and ability to be used with other agricultural chemicals (Koppenhöfer, 2000). Only the infective third-stage juveniles (IJ) of these nematodes are found free living in soil and non-feeding stages, under diverse ecological conditions and in all kinds of habitats (Hominick et al., 1996), being able to survive in soil for extended periods, until they find a suitable host. EPN are distributed worldwide, and include more than 16 species of Heterorhabditis and at 
least 60 species of Steinernema (Nguyen \& Hunt, 2007). They are obligate parasites of insects that form complex, highly virulent symbiotic relationships with enterobacteria, Xenorhabdus-Steinernematidae and Photorhabdus-Heterorhabditidae (Boemare, 2002). As parasites of insects, they have a wide range of hosts (Kaya \& Gaugler, 1993) being used in crop protection in Australia, Europe, USA and Asia (Georgis et al., 2006).

The study of their genetic diversity is extremely important because new species and/or isolates may be useful as biological control agents against agriculturally important pests (Stock, 2009). The detection and identification of indigenous EPN isolates is of major importance, due to differences in strain virulence against natural and local insect pests, environmental conditions that may affect their survival and reproductive potential (Stock, 2009). Several surveys on EPN have already been conducted in Mediterranean countries, namely Egypt (Shamseldean \& Abd- Elgawad, 1994), Greece (Menti et al., 1997), Italy (Triggiani \& Tarasco, 2000), Israel (Glazer et al., 1991), Palestine (Iraki et al., 2003), Spain (García del Pino, 2005; Campos-Herrera et al., 2007) and Turkey (Hazir et al., 2003). Recently, surveys have been conducted in several European countries, such as Austria (Hozzank et al., 2003), Belgium (Midituri et al., 1997), Bulgaria (Shishiniova et al., 2000), Czechoslovakia (Mráček et al., 1999), Denmark (Nielsen \& Philipsen, 2003), France (Emelianoff et al., 2008), Germany (Sturhan \& Ruess, 1999), Poland (Bednarek, 1998), Russia (Ivanova et al., 2000), Slovakia (Sturhan \& Liskova, 1999), Switzerland (Steiner, 1996) and United Kingdom (Gwynn \& Richardson, 1996). Entomopathogenic nematodes show significant variation in behaviour, host range, infectivity, reproduction and tolerance to adverse environmental conditions and therefore it is of major interest to fully characterize natural populations (Stock, 2009).

Studies on the genera Steinernema and Heterorhabditis have been conducted using molecular methods, such as random amplification of polymorphic DNA (RAPD) (Liu \& Berry, 1996) and restriction fragment length polymorphism (RFLP) (Reid et al., 1997). After several tested methods, sequencing of different regions of the genome has become the most suitable approach, not only for assessing phylogenetic relationships, but also for species delimitation (Stock, 2009). Among nuclear genes, ribosomal genes have been used extensively at different taxonomic levels. Ribosomal genes include the $18 \mathrm{~S}$ rRNA gene, the internal transcribed spacers (ITS1 and ITS2), the 5.8S and the 28S rRNA genes, which contain variable and conserved regions (Stock, 2009). The 5.8S rRNA gene is a highly conserved region, contrary to the ITS1 and ITS2 regions, which evolve at a higher rate than the $18 \mathrm{~S}$ and $28 \mathrm{~S}$ rRNA genes, making them ideal for phylogenetic studies at species and population levels (Nguyen et al, 2001; Spiridonov et al., 2004; Stock, 2009). Sequences of the D2D3 expansion region of the 28S rRNA gene were used by some authors to characterize EPN populations (Stock et al., 2001) and may yield more information than the ITS region. On the other hand, mitochondrial cytochrome $c$ oxidase subunit I (COXI) and cytochrome $b$ (cytb) genes evolve more slowly, being better suited for deeper lineage phylogenies (Stock, 2009). Mitochondrial DNA sequences may be more useful in genetic diversity studies (Edgington et al., 2010).

The genus Steinernema is divided into five phylogenetic groups based on the D2D3 expansion region of the 28S rRNA gene and infective juveniles' length (Nguyen \& Hunt, 2007): 'bicornutum-group', 'carpocapsae-group', 'feltiae-group', 'glaseri-group' and 'intermedium-group'.

Earlier reports of EPN in Portugal were conducted in the Azores archipelago (Simões et al., 1994; Rosa \& Simões, 2004), where several surveys have been undertaken as part of a wide programme to find endemic biological agents to control insect pests of pastures. These previous studies described the presence of Steinernema carpocapsae, S. glaseri and Heterorhabditis bacteriophora in the Azores (Simões et al., 1994; Rosa \& Simões, 2004). Until 2006, there were no studies on entomopathogenic nematodes from continental Portugal. The first published report was on the identification of three isolates (I1, I8 and H9) of S. feltiae based on ITS sequence (Valadas et al., 2007). Later, three other isolates (I3, R7 and X7), were identified as $H$. bacteriophora using both ITS sequence and morphological characterization (Valadas et al., 2009). More recently, three other species, S. intermedium (isolate 2B), S. kraussei (isolate 20F) and Steinernema sp. (isolates 59F and 15G) have been described (Valadas et al., 2011), using morphological and molecular data.

It is known that EPN distribution depends on temperature and precipitation and is closely related to vegetation type and presence of insect hosts. Soil type and texture are also very important parameters which influence EPN distribution (Campos-Herrera et al., 2011; El Borai et al., 2012). Continental Portugal has a wide diversity of crops, such as fruit trees, cereals and vegetables, and natural habitats, such as conifer forests and grasslands. These habitats are subject to insect pests which every year cause significant losses in agricultural production.

The major objectives of this research were to determine the distribution of EPN in continental Portugal and to characterize the different species using several molecular markers.

\section{Materials and methods}

Survey zones and sampling procedures

Between 2006 and 2009, 791 soil samples were haphazardly collected across continental Portugal, divided into five NUTS (Nomenclature of Territorial Units for Statistics): Norte, Centro, Lisboa e Vale do Tejo (herein designated as Lisboa), Alentejo and Algarve (http:/ / www.igeo.pt/atlas/Cap3/Cap3f_1.html) (see TableS1, available online).

According to Köppen's climate classification (Köppen \& Geiger, 1928), continental Portugal is divided in two regions: one temperate with rainy winters and dry, hot summers (Csa) and another temperate with rainy winters and dry, cool summers (Csb). Vegetation is affected by climate and, thus, continental Portugal has three kinds of influence: Atlantic, Continental and Mediterranean, Atlantic being predominant. Soil samples were collected from both cultivated and non-cultivated areas, covering the two climatic regions of continental Portugal, 
including different vegetation types, such as irrigated land, forests, grasslands and cultivated fields, among others. Three to four subsamples were collected at $0-20 \mathrm{~cm}$ and used to create a single sample representative of $200 \mathrm{~m}^{2}$. Soil samples were properly dated and identified with GPS (Global Positioning System) (Garmin, Olathe, Kansas, USA) location.

Soil and vegetation types were mapped with ArcGIS software version 10.0 (ESRI; http://www.esri.com/) using Food and Agriculture Organization soil classification (FAO, 2006) and Coordination of information on the environment (CORINE) land cover classification (Caetano et al., 2009). Temperature and precipitation data were obtained from 'PORDATA, Base de Dados Portugal Contemporâneo' (http://www.pordata.pt).

\section{Nematode recovery, propagation and identification}

EPN were recovered from soil samples using the baiting technique, described by Bedding \& Akhurst (1975). Before processing, samples were homogenized and then baited with ten last instar larvae of Galleria mellonella placed inside a perforated metal tea bag, partly filled with soil which was embedded in the soil sample. Soil samples were stored in the dark at $25^{\circ} \mathrm{C}$ and dead G. mellonella were removed and replaced every 4 days for a total of 12 days of baiting. Collected G. mellonella were transferred to White traps (White, 1927) and IJ recovered for the 5-12 following days. IJ were stored in distilled water at $10^{\circ} \mathrm{C}$. To establish new cultures, emerging nematodes were pooled for each sample and used to infect new G. mellonella larvae. Only IJ collected during the week after the first emergence from the insect cadavers were used to establish new cultures. The colour of G. mellonella cadavers, which ranges from cream to brown (Steinernema spp.) or red (Heterorhabditis spp.) within 24-48 h after nematode penetration, was used for preliminary determination of EPN genera. Further identification of the genera of all 53 isolates was carried out by the method of Nguyen \& Hunt (2007) and by sequencing the rRNA ITS region (Nguyen et al., 2001).

\section{Sequencing of ribosomal regions and mitochondrial genes}

For each isolate, genomic DNA was extracted from a suspension of $50 \mu \mathrm{l}$ with more than 10,000 nematodes. Total DNA was extracted with the JETQUICK Tissue
DNA Spin Kit extraction kit (GENOMED, Löhne, Germany), according to the manufacturer's protocol. DNA was used for sequence analysis of ribosomal ITS regions and D2D3 region of the 28S rRNA gene, and mitochondrial genes $c y t b$ and COXI. Nematode DNA was kept at $-20^{\circ} \mathrm{C}$ for further use.

Polymerase chain reactions (PCR) containing $1 \times$ PCR buffer (Fermentas, Vilnius, Lithuania), $1.5 \mathrm{mM} \mathrm{MgCl}_{2}$ (Fermentas), $200 \mu \mathrm{M}$ of each deoxyribonucleoside triphosphate (dNTP) (Fermentas), $0.4 \mu \mathrm{M}$ of each primer (with the exception of $c y t b$ primers, which were used at a concentration of $1 \mu \mathrm{M}$ each) (Stabvida, Caparica, Portugal), 2.5 units of Taq DNA polymerase (recombinant) (Fermentas) and $5 \mu \mathrm{l}$ template DNA (10-20ng) were used (total volume $50 \mu \mathrm{l})$. Primers and PCR amplification conditions for each region and gene are presented in table 1.

All PCR products were analysed by electrophoresis in $1 \%$ agarose gels with Tris-borate buffer, stained in ethidium bromide, purified with GFX PCR DNA and Gel Band Purification Kit (GE Healthcare, Uppsala, Sweden) and sequenced at Stabvida, Portugal.

\section{Phylogenetic analysis}

Multiple sequence alignments of ITS, D2D3 region of the $28 \mathrm{~S}$ rRNA gene, COXI and $c y t b$ sequences were assembled using the ClustalW algorithm as implemented in BioEdit version 7.1.3.0 (Hall, 1999), under default alignment parameters. The best-fitting evolutionary model of nucleotide substitutions was determined, using MEGA5 version 5.05 (Tamura et al., 2011) and phylogenetic relationships among isolates were reconstructed by neighbour-joining (Saitou \& Nei, 1987) and maximum likelihood (ML) methods. Gaps or indels were treated using the complete deletion option. Bootstrap analysis was performed with 100 replicates (Felsenstein, 1985). Sequences were compared with those from reference organisms/strains available in the GenBank database.

\section{Data analysis}

Statistical analysis was performed using PASW Statistics 18 release 18.0.0 software (SPSS Inc., Chicago, Illinois, USA). Relationships between species and NUTS, vegetation or soil types were determined using the chi-square test of association. Results are presented as the test statistic $\left(\chi^{2}\right)$, degrees of freedom $(\mathrm{df})$ and probability of equal or greater deviation $(P)$.

Table 1. Primers used for sequencing reactions of ribosomal regions and mitochondrial genes.

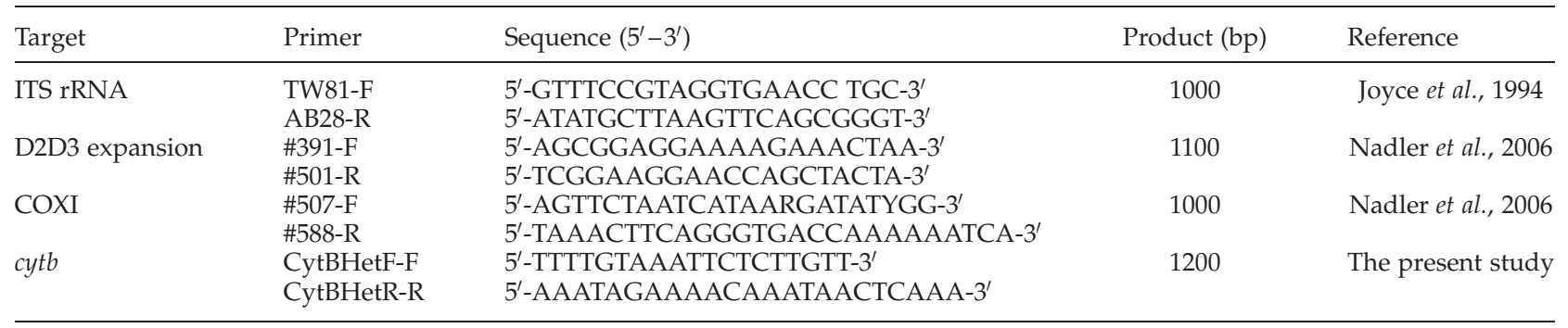


Correspondence analysis (CA) was used as an explorative method to study associations and to reveal interdependencies between each two of the above-mentioned variables. Visualization using CA is based on representing chi-square distances among species and NUTS, vegetation or soil types.

\section{Results}

\section{Data analysis}

EPN were recovered from 53 of the 791 sampled sites $(6.7 \%)$ (fig. 1). Nine soil samples $(17 \%)$ were positive for the occurrence of heterorhabditids and 44 (83\%) for steinernematids, identified as described. Nematodes isolated from the positive samples were further identified to the species level based on ITS sequences.

Although there is no association between species and NUTS $(P>0.1)$ (table 2$)$, the CA biplot revealed that $H$. bacteriophora isolates are more abundant in the Alentejo region. The nine positive samples for $H$. bacteriophora were recovered from sites below the altitude of $400 \mathrm{~m}$. Steinernema feltiae was detected from 40 sites $(75.5 \%)$ in locations where the altitude varies between 13 and $878 \mathrm{~m}$. No association was found between species and climate $(P>0.05)$.

\section{Habitat and soil types}

Positive samples were most commonly found in mixed forest, land occupied by agriculture with natural vegetation, broadleaved forest and transitional woodland-shrub (table 3). Heterorhabditis bacteriophora was found in a wide range of habitats including: mixed forest, transitional woodland-shrub, vineyards, broadleaved forest, land occupied by agriculture with natural vegetation and permanently irrigated land (table 3). Steinernema feltiae was present in all kinds of habitats containing EPN, being more abundant in land occupied by agriculture with natural vegetation, broadleaved forest, mixed forest, transitional woodland-shrub, agroforestry areas, complex cultivated patterns and nonirrigated arable land (table 3). Steinernema intermedium was found in a mixed forest and S. kraussei in moors and heathland habitat (table 3). The Steinernema sp. isolates were found in a broadleaved forest and in a mixed forest (table 3). There is an association between species and vegetation type $\left(\chi^{2}=83.438, \mathrm{df}=60, P>0.05\right)$ (fig. 2 ). Furthermore, the CA biplot showed that the most abundant species, S. feltiae, is present mainly in land occupied by agriculture with natural vegetation, broadleaved forest, fruit trees and berry plantations, olive groves and non-irrigated arable land (fig. 2). Steinernema feltiae was found in almost all soil types, namely cambisols, podzols, luvisols, lithosols and regosols, whereas $H$. bacteriophora was only found in lithosols, podzols, cambisols and luvisols (table 4). The Steinernema sp. isolates were found in a lithosol and a cambisol. Steinernema kraussei and $S$. intermedium isolates were found in a cambisol and a podzol, respectively (table 4).

No association was found between species and soil type $(P>0.1)$. However, the CA biplot indicates that the two most abundant species are not randomly distributed by the different soil types: $S$. feltiae was mostly recovered from luvisols, but also from cambisols and regosols; $H$. bacteriophora is more abundant in lithosols. Heterorhabditis bacteriophora was found in soil samples with $\mathrm{pH}$ values between 4.37 and 7.92, whereas $S$. feltiae was present in soils with $\mathrm{pH}$ values between 4.02 and 8.11. Steinernema intermedium and S. kraussei were found in soils with $\mathrm{pH}$ 4.17-5.34. Steinernema sp. isolates were recovered in soils with $\mathrm{pH}$ values of 4.90 and 6.23. No association was found between species and the soil's physical and chemical characteristics $(P>0.05)$.

\section{Phylogenetic analysis of ITS, D2D3, COXI and cytb}

Nematodes isolated from the positive samples were identified based on ITS sequences as $S$. feltiae (40 isolates), S. intermedium (one isolate), S. kraussei (one isolate), Steinernema sp. (two isolates) and $H$. bacteriophora (nine isolates) (fig. 3). Because S. feltiae and H. bacteriophora were the two most abundant EPN species, D2D3 region of the 28S rRNA gene, COXI and cytb genes were used to further evaluate the genetic diversity of the populations. Repeated attempts to amplify and sequence some genes for some isolates were unsuccessful, thus justifying the discrepant number of isolates in the different phylogenies.

\section{ITS phylogenies of $\mathrm{S}$. feltiae and $\mathrm{H}$. bacteriophora}

For 37 S. feltiae and eight H. bacteriophora Portuguese isolates, a PCR product of approximately $1000 \mathrm{bp}$, containing the partial sequence of ITS1 and ITS2, and the whole 5.8S rRNA gene, was obtained and sequenced. Heterorhabditis bacteriophora was included as outgroup (fig. 3).

Three sequence types were obtained with six $S$. feltiae isolates being used for phylogenetic analyses, namely isolate $11 \mathrm{~A}$, which also represents $24 \mathrm{~A}$; isolates $32 \mathrm{~A}$ and $86 \mathrm{E}$, representing 93E, $\mathrm{I} 1$ and $\mathrm{Z} 8$; and isolates $\mathrm{I} 2,22 \mathrm{~A}$ and $\mathrm{H} 9$ representing the remaining isolates.

Comparing the six Portuguese with foreign S. feltiae isolates, few polymorphisms were found. All Portuguese and foreign $S$. feltiae isolates group in the same cluster, together with the other species from the 'feltiae-group' (S. oregonense and S. kraussei) sharing sequence identities between 94 and 100\% (fig. 3). Steinernema feltiae Portuguese isolates showed some genetic diversity, which is represented by isolates $11 \mathrm{~A}, 22 \mathrm{~A}, \mathrm{H} 9$ and $\mathrm{I} 2$, together with S. feltiae from Spain, which share sequence identities between 99.6 and $99.8 \%$. Portuguese isolates $86 \mathrm{E}$ and $32 \mathrm{~A}$, together with the remaining $S$. feltiae foreign isolates, share sequence identities between 94 and 99.8\%. Other species belonging to the 'feltiae-group', S. kraussei and S. oregonense, as well as S. kraussei isolate $20 \mathrm{~F}$, share sequence identities between 56 and $95 \%$ with foreign and Portuguese isolates. Isolates $15 \mathrm{G}$ and 59F share the highest identity with species of the 'glaseri-group' (75-85\%), suggesting that Steinernema sp. belong to this group (fig. 3). Grouping with the major cluster are species belonging to 'carpocapsae-group' and 'bicornutum-group'.

The most distant group includes the two species from the 'intermedium-group', S. intermedium and S. affine, and the Portuguese isolate $2 \mathrm{~B}$ of the species $S$. intermedium. Species from the 'intermedium-group' share identities 


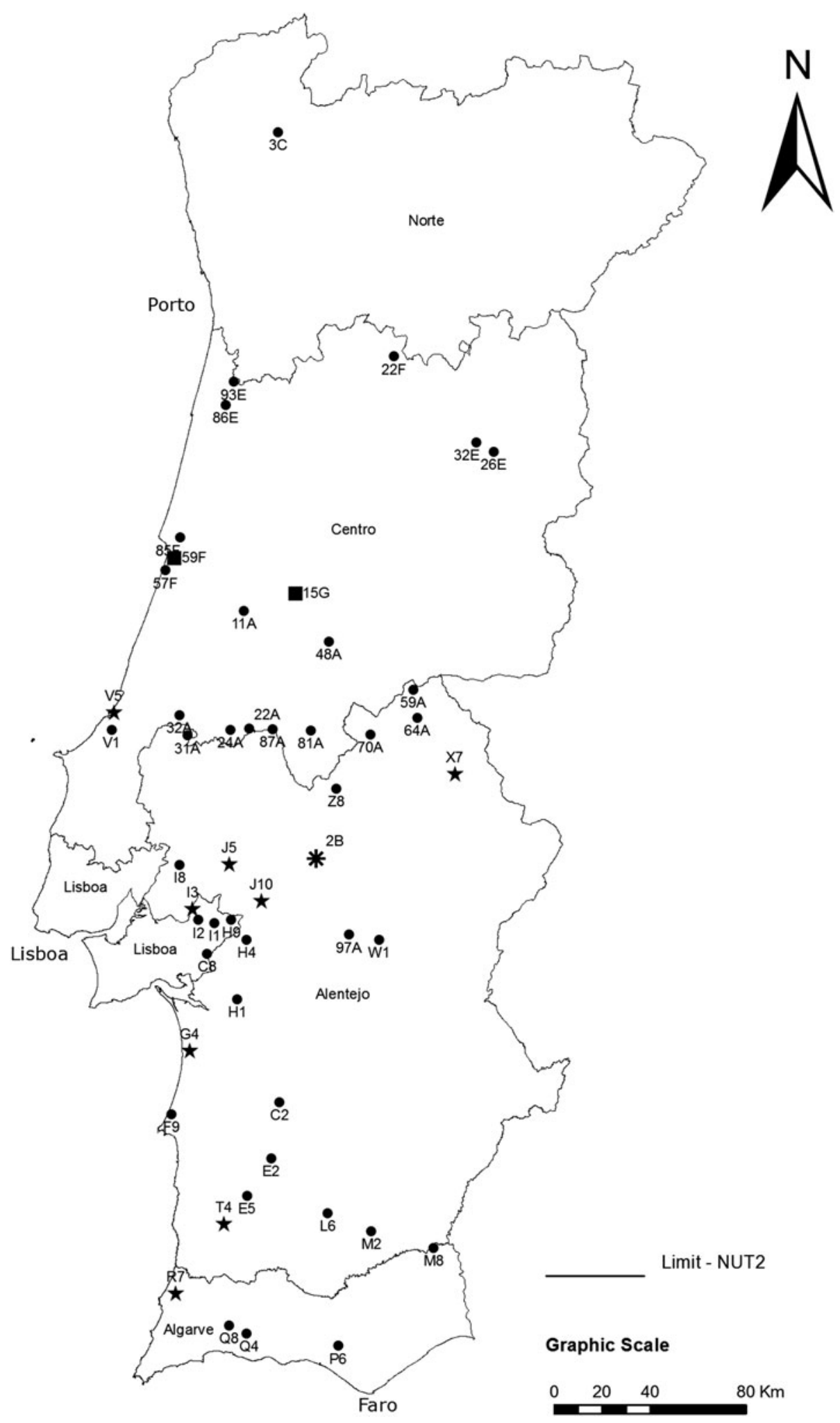

Fig. 1. Entomopathogenic nematode distribution across the five NUTS (Nomenclature of Territorial Units for Statistics) of continental Portugal. Each point is marked with the name of the isolate and the corresponding species. Map based on the CAOP (Carta Administrativa e Oficial de Portugal; http:/ /www.igeo.pt). Steinernema sp., $\mathbf{\square}$ S. feltiae, $\bullet ;$ S. kraussei, $\mathbf{\Delta}$; S. intermedium, *; Heterorhabditis bacteriophora, $\star$. 
Table 2. The occurrence of entomopathogenic nematodes in continental Portugal using NUTS (Nomenclature of Territorial Units for Statistics) (CAOP; http:/ / www.igeo.pt), relative to total area covered and the proportion of EPN species recovered.

\begin{tabular}{|c|c|c|c|c|c|}
\hline NUTS & Area $\left(\mathrm{km}^{2}\right)$ & Area $(\%)$ & $\begin{array}{l}\text { Number } \\
\text { of samples }\end{array}$ & Number of EPN & $\begin{array}{c}\text { Positive } \\
\text { samples } \\
(\%)\end{array}$ \\
\hline Norte & 21285.876 & 23.89 & 268 & 1 & $1.9^{1}$ \\
\hline Centro & 28199.404 & 31.65 & 207 & 19 & $28^{1} ; 1.9^{3} ; 3.8^{4} ; 1.9^{5}$ \\
\hline Lisboa e Vale do Tejo & 3001.938 & 3.37 & 84 & 5 & $7.5^{1} ; 1.9^{5^{\prime}}$ \\
\hline Alentejo & 31604.906 & 35.48 & 181 & 23 & $30.2^{1} ; 1.9^{2} ; 11.3^{5}$ \\
\hline Algarve & 4996.795 & 5.61 & 51 & 5 & $7.5^{1} ; 1.9^{5}$ \\
\hline
\end{tabular}

${ }^{1}$ Steinernema feltiae;

${ }^{2}$ S. intermedium;

${ }^{3}$ S. kraussei;

${ }^{4}$ Steinernema sp.;

${ }^{5}$ Heterorhabditis bacteriophora.

between 93 and $99 \%$ and have $57-86 \%$ sequence identity with species from the 'feltiae-group' (fig. 3).

ITS sequences indicate that all Portuguese Heterorhabditis isolates belong to the species $H$. bacteriophora. The eight Portuguese isolates of $H$. bacteriophora are $100 \%$ identical in sequence and all group together with foreign $H$. bacteriophora isolates (with bootstrap support of $98 \%$ ), sharing identities of $98-100 \%$ (data not shown). Heterorhabditis zealandica also groups inside this cluster, sharing $96-97 \%$ identity with $H$. bacteriophora isolates. The most distant species from $H$. bacteriophora are $H$. indica, $H$. floridensis, $H$. amazonensis and $H$. baujardi, sharing $70-72 \%$ identity with $H$. bacteriophora isolates (data not shown). Heterorhabditis marelatus and H. megidis are more similar to $H$. bacteriophora (sequence identity between 74 and $79 \%$ ) than the previous species.

\section{S. feltiae and $\mathrm{H}$. bacteriophora D2D3 phylogenies}

The D2D3 expansion region of the 28S rRNA gene sequences confirms the previous identification of EPN isolates as S. feltiae and H. bacteriophora.

For 27 S. feltiae and seven H. bacteriophora Portuguese isolates, a PCR product of approximately $1100 \mathrm{bp}$, containing the partial sequence of the D2D3 region of the $28 \mathrm{~S}$ rRNA gene, was obtained and sequenced. From the 27 , only five representative isolates were used in the phylogenetic analysis, because the others share $100 \%$ sequence identity with these isolates (isolate $3 \mathrm{C}$ represents isolates $11 \mathrm{~A}, 22 \mathrm{~A}, 22 \mathrm{~F}, 24 \mathrm{~A}, 57 \mathrm{~F}, 59 \mathrm{~A}, 70 \mathrm{~A}, 85 \mathrm{~F}$, 87A, C8, E2, F9, H1, H9, I2, I8, L6 and P6; and isolate 32A stands for isolates 86E, 93E, V1 and I1) (fig. 4). Globodera pallida was included as outgroup, considering that the D2D3 H. bacteriophora sequence was too close to species from the 'carpocapsae-group' to serve this purpose.

Comparing the five Portuguese isolates of S. feltiae with foreign S. feltiae, only a few polymorphisms were found. All Portuguese and foreign S. feltiae isolates group in the same cluster sharing $99-100 \%$ sequence identity with $99 \%$ bootstrap support, showing no genetic diversity between isolates (fig. 4). Steinernema feltiae isolates group with species from the 'feltiae-group' (S. monticolum and S. kraussei) sharing sequence identities of 92-98\% (bootstrap support 77\%). Regarding the D2D3 phylogeny, no polymorphisms were found among $H$. bacteriophora Portuguese isolates. One major cluster was obtained, which contains all Portuguese isolates and the reference strains of $H$. bacteriophora (bootstrap support 98\%). All $H$. bacteriophora isolates are $100 \%$ identical in sequence (data not shown). The closest species to H. bacteriophora is $H$. megidis, sharing a sequence identity between 91 and $93 \%$; the most distant is $H$. indica, with a sequence identity of $90 \%$.

\section{S. feltiae COXI gene phylogeny}

From the 23 Portuguese S. feltiae isolates, only 16 representative isolates were used for phylogenetic analysis (isolate $3 \mathrm{C}$ represents $87 \mathrm{~A}$; isolate $11 \mathrm{~A}$ represents $22 \mathrm{~F}$ and $70 \mathrm{~A}$; isolate $\mathrm{H} 9$ represents $\mathrm{F} 9$; isolate $24 \mathrm{~A}$ represents P6; isolate I2 represents $\mathrm{H} 1$ and I8). Heterorhabditis bacteriophora was included as outgroup. A PCR product of approximately $1000 \mathrm{bp}$, containing the partial sequence of the COXI gene was obtained and sequenced for the Portuguese isolates.

There is a large cluster that includes all S. feltiae Portuguese isolates, together with the reference species of S. feltiae, sharing sequence identity values between 94 and $100 \%$ (bootstrap support of $99 \%$ ) (fig. 5). Inside this major cluster there is some diversity between Portuguese isolates (sequence identity values of $97-100 \%$ ), in some cases supported by bootstrap values that vary between 36 and $95 \%$ (fig. 5). For example, isolates $59 \mathrm{~A}$ and $85 \mathrm{~F}$ form a group sharing a sequence identity of $99.5 \%$, grouping also with isolate $\mathrm{H} 9$, with whom they share a sequence identity of $99 \%$. All S. feltiae Portuguese isolates share high sequence identity values $(98-100 \%)$. This major cluster groups with S. kraussei and S. oregonense, both species of the 'feltiae-group' sharing identities of $85-87 \%$ (fig. 5). The entire previous clade clusters together with species belonging to the 'intermedium-group', the 'bicornutum-group', the 'glaseri-group' and the 'carpocapsaegroup' (fig. 5). The Steinernema sp. isolates 15G and 59F, group together sharing similarities of $92 \%$. These isolates seem to represent a putative new species inside the 'glaseri-group', with whom they share $87-90 \%$ sequence identity (fig. 5). 
Table 3. The occurrence of entomopathogenic nematodes in the study, relative to the three classes of vegetation based on the 'Land Cover Nomenclature' (Caetano et al., 2009).

\begin{tabular}{|c|c|c|c|c|c|}
\hline \multicolumn{3}{|c|}{ Vegetation type } & \multirow[b]{2}{*}{$\begin{array}{l}\text { Number of } \\
\text { samples }\end{array}$} & \multirow[b]{2}{*}{$\begin{array}{l}\text { Number of } \\
\text { EPN }\end{array}$} & \multirow[b]{2}{*}{$\begin{array}{c}\text { Positive } \\
\text { samples (\%) }\end{array}$} \\
\hline (type I) & (type II) & (type III) & & & \\
\hline Artificial surfaces & Urban fabric & Discontinuous urban fabric (112) & 47 & 2 & $3.8^{1}$ \\
\hline Artificial surfaces & Industrial, commercial and transport units & Industrial or commercial units (121) & 6 & 0 & 0 \\
\hline Artificial surfaces & Industrial, commercial and transport units & $\begin{array}{l}\text { Road and rail networks and } \\
\text { associated land (122) }\end{array}$ & 1 & 0 & 0 \\
\hline Artificial surfaces & Mine, dump and construction sites & Construction sites (133) & 1 & 0 & 0 \\
\hline Agricultural areas & Arable lands & Non-irrigated arable land (211) & 47 & 3 & $5.7^{1}$ \\
\hline Agricultural areas & Arable lands & Permanently irrigated land (212) & 39 & 3 & $3.8^{1}: 1.9^{5}$ \\
\hline Agricultural areas & Arable lands & Rice fields (213) & 10 & 0 & 0 \\
\hline Agricultural areas & Permanent crops & Vineyards (221) & 15 & 2 & $3.8^{5}$ \\
\hline Agricultural areas & Permanent crops & Fruit trees and berry plantation (222) & 13 & 2 & $3.8^{1}$ \\
\hline Agricultural areas & Permanent crops & Olive groves (223) & 20 & 2 & $3.8^{1}$ \\
\hline Agricultural areas & Pastures & Pastures (231) & 2 & 0 & 0 \\
\hline Agricultural areas & Pastures & Artificial grasslands (232) & 1 & 0 & 0 \\
\hline Agricultural areas & Heterogeneous agricultural areas & $\begin{array}{l}\text { Annual crops associated } \\
\text { with permanent crops (241) }\end{array}$ & 71 & 0 & 0 \\
\hline Agricultural areas & Heterogeneous agricultural areas & Complex cultivation patterns (242) & 89 & 3 & $5.7^{1}$ \\
\hline Agricultural areas & Heterogeneous agricultural areas & $\begin{array}{l}\text { Land occupied by agriculture } \\
\text { with natural vegetation }(243)\end{array}$ & 43 & 7 & $11.3^{1} ; 1.8^{5}$ \\
\hline Agricultural areas & Heterogeneous agricultural areas & Agro-forestry areas (244) & 21 & 3 & $5.7^{1}$ \\
\hline Forest and semi-natural areas & Forests & Broadleaved forest (311) & 77 & 6 & $7.5^{1} ; 1.9^{4} ; 1.9^{5}$ \\
\hline Forest and semi-natural areas & Forests & Coniferous forest (312) & 57 & 1 & $1.9^{1}$ \\
\hline Forest and semi-natural areas & Forests & Mixed forest (313) & 58 & 8 & $7.5^{1} ; 1.9^{2} ; 1.9^{4} ; 3.8^{5}$ \\
\hline Forest and semi-natural areas & Scrub and/or herbaceous vegetation associations & Natural grasslands (321) & 30 & 2 & $3.8^{1}$ \\
\hline Forest and semi-natural areas & Scrub and/or herbaceous vegetation associations & Moors and heathland (322) & 16 & 1 & $1.9^{3}$ \\
\hline Forest and semi-natural areas & Scrub and/or herbaceous vegetation associations & Sclerophyllous vegetation (323) & 14 & 0 & 0 \\
\hline Forest and semi-natural areas & Scrub and/or herbaceous vegetation associations & Transitional woodland-shrub (324) & 94 & 6 & $7.5^{1} ; 3.8^{5}$ \\
\hline Forest and semi-natural areas & Open spaces with little or no vegetation & Beaches, dunes, sands (331) & 3 & 0 & 0 \\
\hline Forest and semi-natural areas & Open spaces with little or no vegetation & Burnt areas (334) & 2 & 0 & 0 \\
\hline Wetlands & Maritime wetlands & Salt marshes (421) & 1 & 0 & 0 \\
\hline Water bodies & Inland waters & Water bodies (511) & 3 & 1 & $1.9^{1}$ \\
\hline Water bodies & Marine waters & Estuaries (522) & 10 & 1 & $1.9^{1}$ \\
\hline
\end{tabular}

${ }^{1}$ Steinernema feltiae

${ }^{2}$ S. intermedium;

${ }^{3}$ S. kraussei;

${ }^{4}$ Steinernema sp.;

${ }^{5}$ Heterorhabditis bacteriophora. 


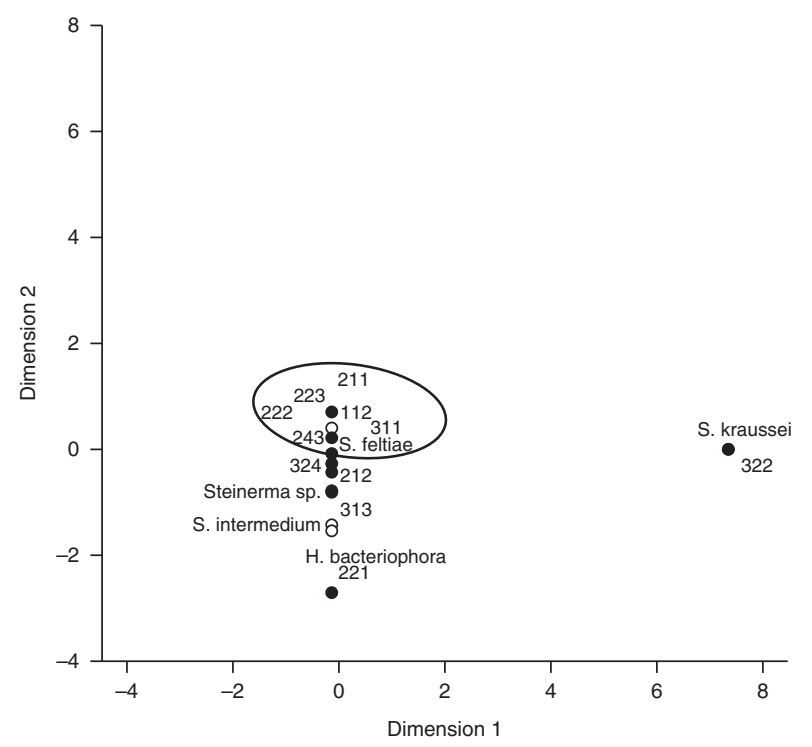

Fig. 2. CA biplot of the relationship between species and (a) NUTS (Nomenclature of Territorial Units for Statistics), (b) vegetation type, (c) soil type. Note: some dots are overlaid. Species, $\mathrm{O}$; vegetation type, $\bullet$

\section{H. bacteriophora cytb gene phylogeny}

For nine H. bacteriophora Portuguese isolates, a PCR product of approximately $1200 \mathrm{bp}$, containing a partial sequence of the cytb gene was obtained and sequenced. Steinernema carpocapsae was included as outgroup. No polymorphisms were found among Portuguese isolates $(100 \%$ identical). One major cluster (bootstrap value of $68 \%$ ) was obtained, which contains all Portuguese isolates sharing $100 \%$ sequence identity (fig. 6). Portuguese isolates share $99.7 \%$ sequence identity with the reference strain of $H$. bacteriophora and $81.6 \%$ with S. carpocapsae (fig. 6).

\section{Discussion}

Even though national surveys already undertaken provide valuable data on EPN distribution (García del Pino \& Palomo, 1996; Kary et al., 2009; Edgington et al., 2010; Khatri-Chhetri et al, 2010; Ma et al., 2010), species habitat preferences are still poorly understood. The present study aimed at understanding the natural occurrence of EPN in continental Portugal, representing the most systematic and extensive survey made for the first time in the country to evaluate indigenous species of EPN.

The survey covered all NUTs, the different climatic regions and a wide variety of vegetation and soil types. Positive soil samples were analysed with the additional information collected, namely temperature and precipitation values, altitude and soil type. Although EPN were recovered at a low rate ( $6.7 \%$ of sampling sites) in our study, five different species were isolated from the entire country: S. feltiae (75\%), H. bacteriophora $(17 \%)$, S. intermedium (1.9\%), S. kraussei $(1.9 \%)$ and Steinernema sp. (3.8\%). Steinernema feltiae and H. bacteriophora were the two most abundant species found in the country. One reason for the low recovery rate obtained in the present study, could be the fact that only one insect, G. mellonella, was used as trap insect, and it may not be the appropriate host for all EPN species (Kary et al., 2009). Also, the fact that just one temperature value $\left(25^{\circ} \mathrm{C}\right)$ was used for soil baiting samples may represent a limitation. The use of just one baiting temperature may not cover all the requirements for other EPN species (Mráček et al., 2005). Furthermore, the choice of sampling sites may contribute to differences in EPN recovery percentage (Mráček et al., 2005). However, this low recovery percentage is not unusual, and it has already been reported from other surveys (Rosa et al., 2000; Hazir et al., 2003; Kary et al., 2009). Furthermore, the low H. bacteriophora recovery rate compared to Steinernema spp. may be due to the fact that this species, as mentioned by Emelianoff et al. (2008), is preferentially located in beaches, which were habitats not sampled in the present study. In addition, H. bacteriophora is highly mobile, responding to chemical signals from the host, and being adapted to infect less mobile insects that are found in lower soil layers (Ishibashi, 2002). Since our samples were collected from the upper soil layer, this could explain the low recovery and genetic diversity of H. bacteriophora found in continental Portugal.

Steinernema feltiae, S. intermedium and H. bacteriophora are considered to be the most common EPN species in Europe, having been detected previously in southern France and in northern Spain (Hominick, 2002). The recovery rates of both Steinernema spp. and $H$. bacteriophora are similar to those of other studies in the Mediterranean area: 1.3\% Heterorhabditis and 22\% Steinernema in Catalonia (García del Pino, 2005), and $5.3 \%$ Heterorhabditis and $8.5 \%$ Steinernema in Italy (Tarasco \& Triggiani, 1997).

In other studies, the percentage recovery of EPN species has varied from 0.7 to $70.1 \%$ (Mráček \& Becvár, 2000; Bruck, 2004). The $6.7 \%$ recovery detected in continental Portugal is within the interval of the expected values $(3.3-23 \%)$ obtained in Spain, which has similar climatic conditions and types of soil and vegetation to continental Portugal (De Doucet \& Gabarra, 1994; García del Pino, 1994, 2005; García del Pino \& Palomo, 1996;

Table 4. The occurrence of entomopathogenic nematodes, relative to soil types (FAO, 2006).

\begin{tabular}{lccc}
\hline Soil type & $\begin{array}{c}\text { Number } \\
\text { of samples }\end{array}$ & $\begin{array}{c}\text { Number } \\
\text { of EPN }\end{array}$ & $\begin{array}{c}\text { Positive } \\
\text { samples }(\%)\end{array}$ \\
\hline Podzols & 99 & 12 & $17^{1} ; 1.9^{2} ; 3.8^{5}$ \\
Cambisols & 359 & 24 & $36^{1} ; 1.9^{3} ; 1.9^{4} ; 3.8^{5}$ \\
Luvisols & 111 & 11 & $17^{1} ; 3.8^{5}$ \\
Lithosols & 155 & 6 & $3.8^{1} ; 1.9^{4} ; 5.7^{5}$ \\
Regosols & 12 & 1 & $1.9^{1}$ \\
Solonchaks & 2 & 0 & 0 \\
Fluvisols & 15 & 0 & 0 \\
No classification & 38 & 0 & 0 \\
\hline
\end{tabular}

\footnotetext{
${ }^{1}$ Steinernema feltiae;

${ }^{2}$ S. intermedium;

${ }^{3}$ S. kraussei;

${ }^{4}$ Steinernema sp.;

${ }^{5}$ Heterorhabditis bacteriophora.
} 


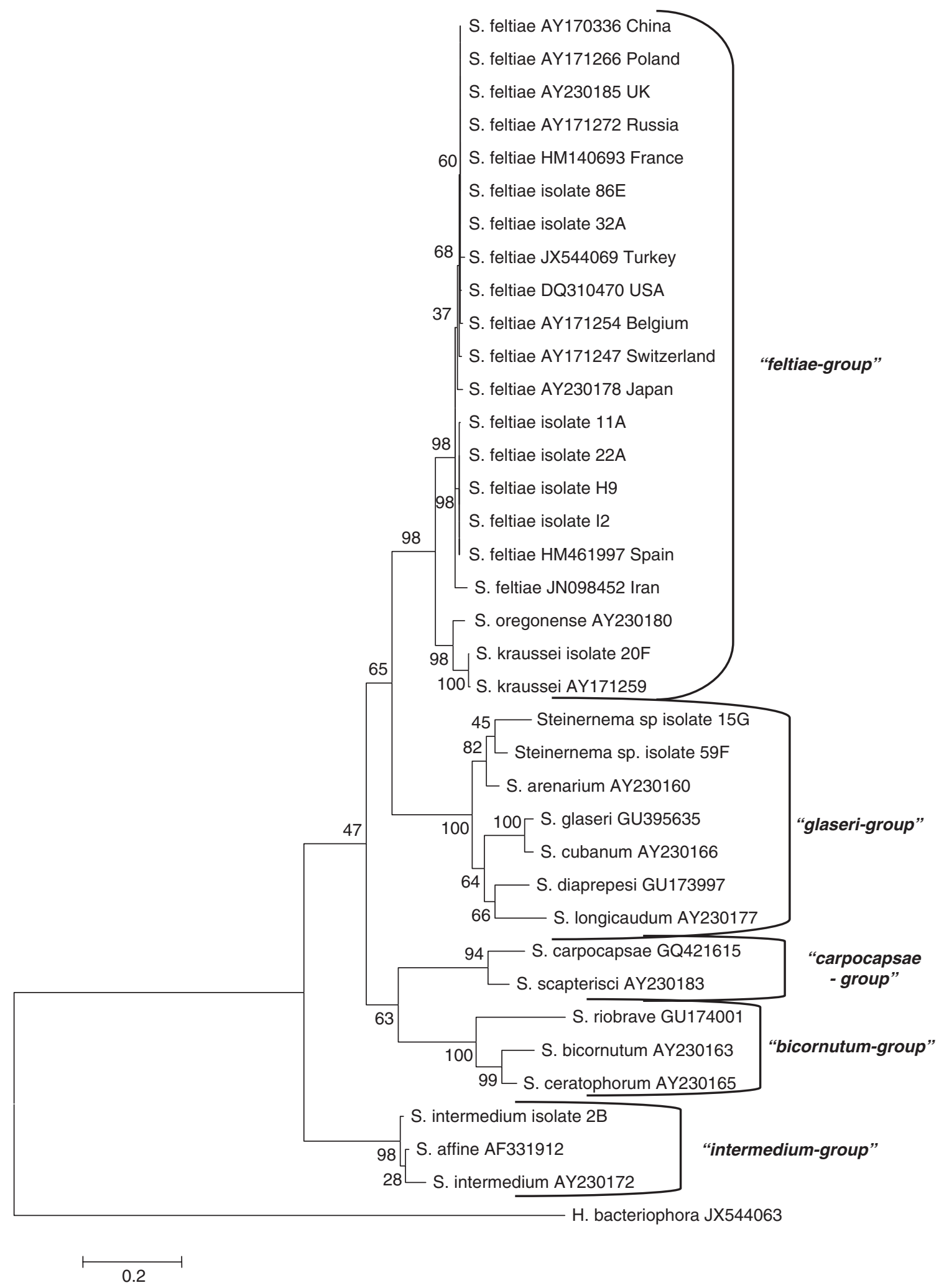

Fig. 3. Maximum likelihood ITS phylogenetic trees using Tamura 3-parameter model (Tamura, 1992), based on nucleotide sequences of Steinernema spp. and reference strains (alignment length 768 bp). Percentage bootstrap is indicated on internal branches (100 replicates); scale bar indicates 0.2 substitutions per site. 


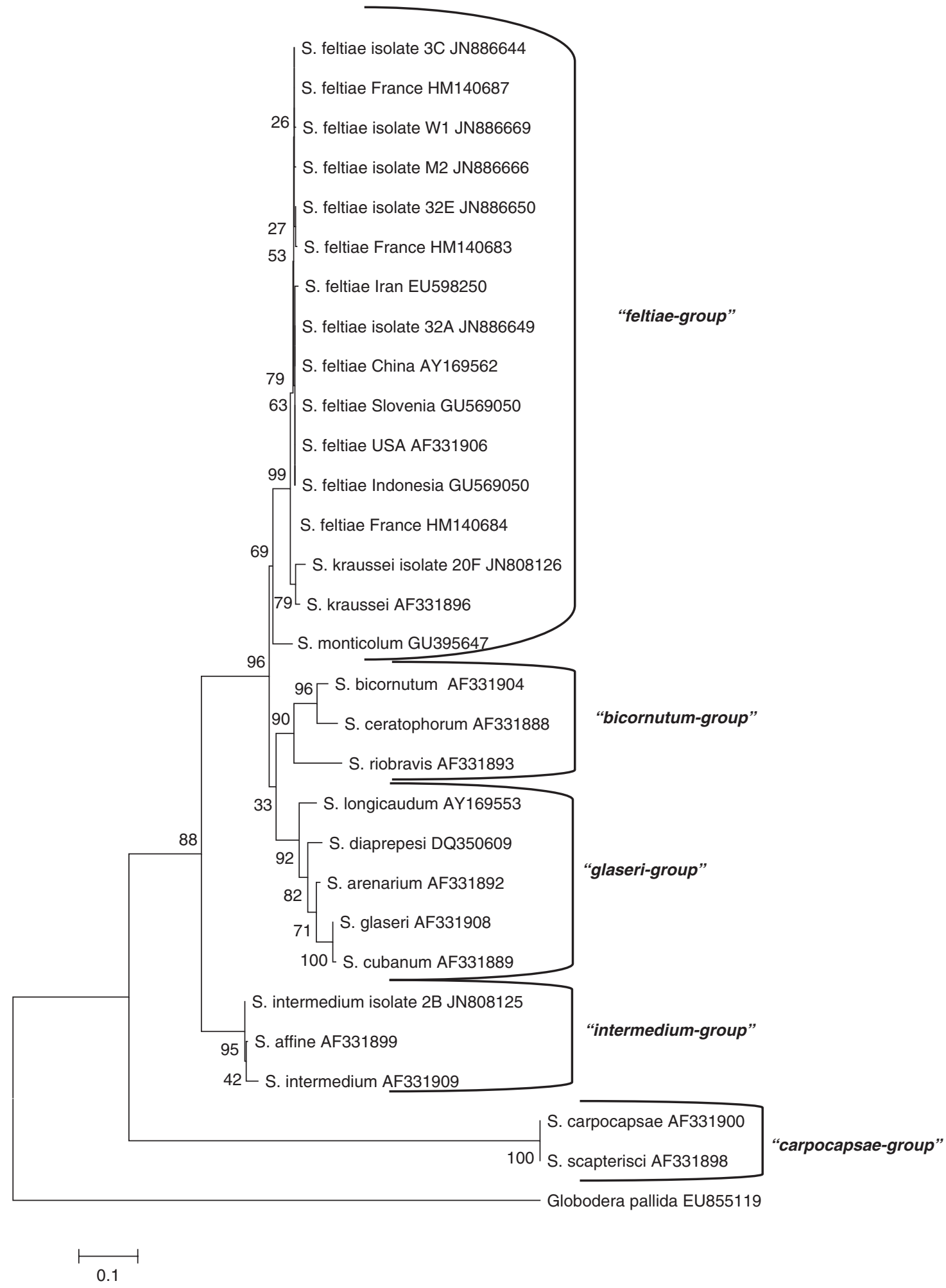

Fig. 4. Maximum likelihood D2D3 phylogenetic tree using Kimura 2-parameter model (Kimura, 1980), based on nucleotide sequences of Steinernema spp. and reference strains (alignment length $469 \mathrm{bp}$ ). Percentage bootstrap is indicated on internal branches (100 replicates); scale bar indicates 0.1 substitutions per site. 


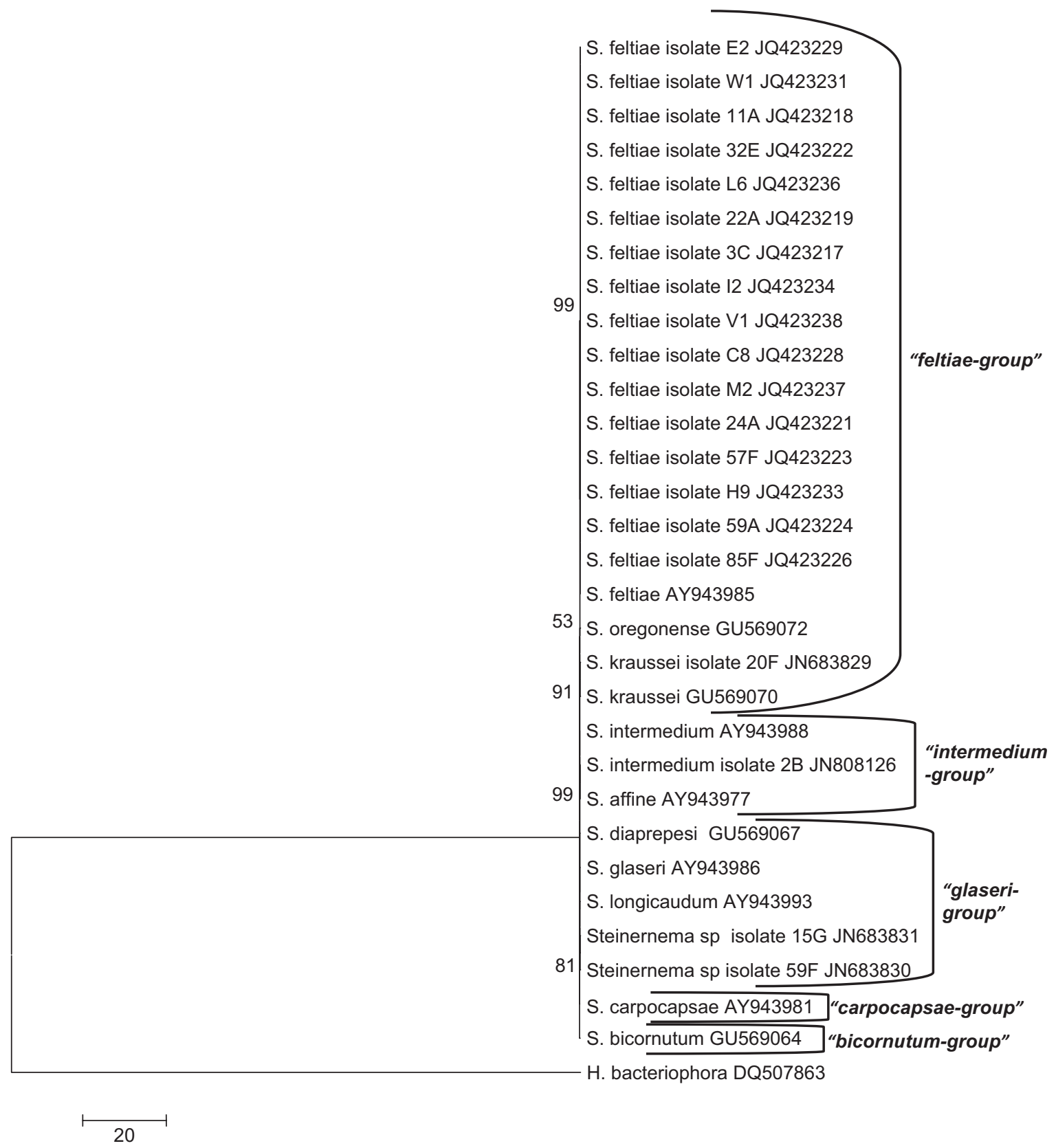

Fig. 5. Maximum likelihood COXI phylogenetic tree using the HKY model (Hasegawa et al., 1985), based on nucleotide sequences of Steinernema spp. isolates and reference strains (alignment length $566 \mathrm{bp}$ ). Percentage bootstrap is indicated on internal branches (100 replicates); scale bar indicates 20 substitutions per site.

Campos-Herrera et al., 2007). Other Mediterranean countries also have similar recovery rates: Greece, 5\% (Menti et al., 1997); Egypt, 10\% (Shamseldean \& AbdElgawad, 1994); Mediterranean Turkey, 5.8\% (Kepenekci, 2002); and Italy, 5-15.5\% (Ehlers et al., 1991; Tarasco \& Triggiani, 1997; Triggiani \& Tarasco, 2000). On the other hand, EPN seem to occur more frequently in northern European countries: Sweden, 25\% (Burman et al., 1986); Czechoslovakia, 37\% (Mráček, 1980); Finland, 37\% (Vänninen et al., 1989); Germany, 1.2\% (Ehlers et al.,
1991); Britain, 48.6\% (Hominick \& Briscoe, 1990); Scotland, 2.2\% (Boag et al., 1992); and Ireland, 10.5-14\% (Downes \& Griffin, 1991; Griffin et al., 1991). The EPN abundance, distribution and habitat preference are related to host-parasite relationships, environmental conditions and soil characteristics (Nielsen \& Philipsen, 2003; Püza \& Mráček, 2005; Campos-Herrera et al., 2007).

Our results show that natural habitats present a higher percentage of positive samples, compared to agricultural ones, probably due to chemical control of insect pests in 


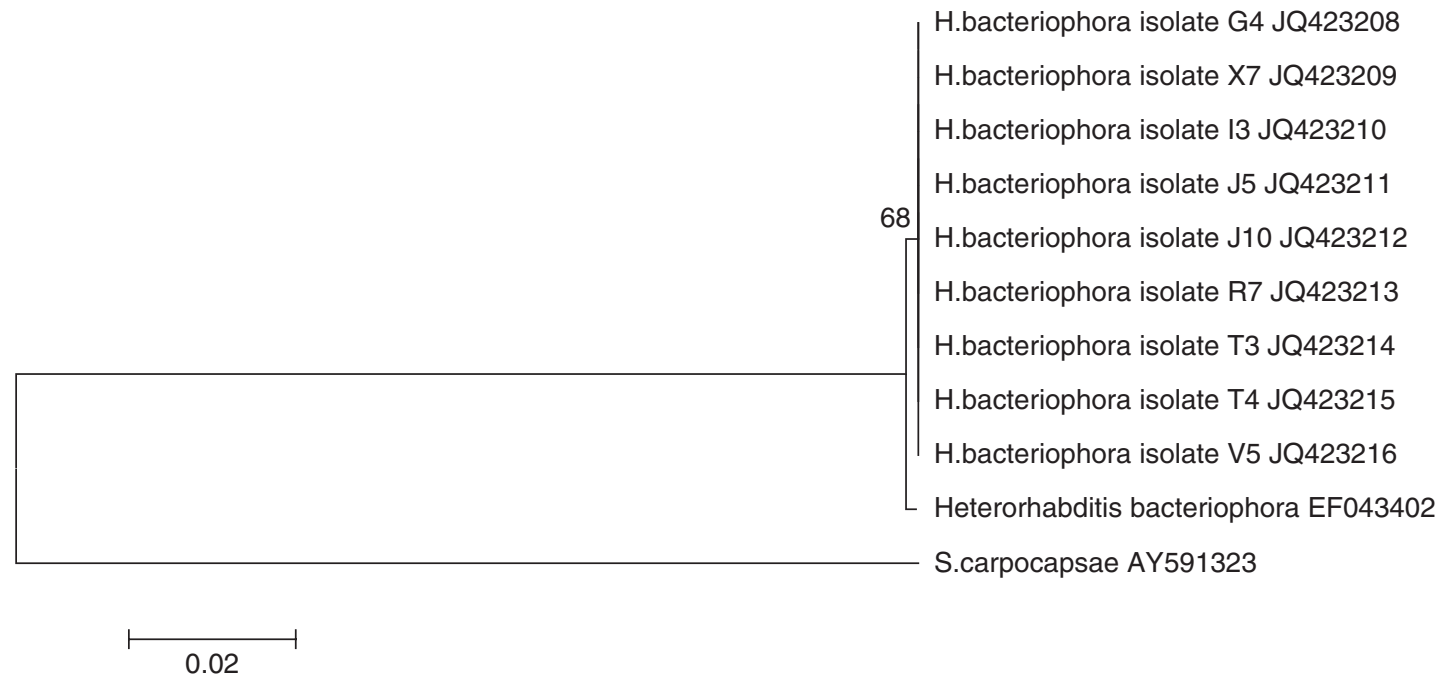

Fig. 6. Maximum likelihood cytb phylogenetic tree using Tamura-Nei model (Tamura \& Nei, 1993), based on nucleotide sequences of $H$. bacteriophora isolates and reference strains (alignment length $749 \mathrm{bp}$ ). Percentage bootstrap is indicated on internal branches (100 replicates); scale bar indicates 0.02 substitutions per site.

agricultural regions, which partially reduces the abundance of natural biocontrol agents. Stock et al. (2008) also claimed a higher abundance of EPN in natural habitats such as forests. EPN were recovered from soils with high sand content, which favour their mobility and survival, such as cambisols, podzols, luvisols followed by lithosols and regosols. Observing the soils' physical and chemical characteristics, no clear relationship was found. Abiotic factors, such as altitude, temperature or rainfall, do not influence the distribution of EPN species. No correlation was observed between genetic diversity of $S$. feltiae isolates and any of the biotic or abiotic parameters that were analysed for these isolates.

Steinernema kraussei and S. intermedium were each found at only one site, in moors and heathland and mixed forests, respectively. The reason for the low recovery of these two species is not known. Steinernema kraussei and S. intermedium are common in Europe, with S. intermedium showing a preference for tree habitats (Nguyen \& Hunt, 2007). Steinernema sp. was recovered from only two sites, in mixed forests and broadleaved forest habitats.

The species nature of the genus Steinernema is a result of its longer evolution history (Adams et al., 2007) and its reproductive patterns (amphimictic and hermaphroditic), making this genus more capable of occupying a wide range of habitats than Heterorhabditis (Edgington et al., 2010). The geographical and habitat preferences of EPN species in continental Portugal may also reflect the chances of dispersal events as well as feeding patterns. However, EPN diversity determined in this study is similar to the diversity reported in previous studies in northern Spain and southern France, which constitute the closest area already sampled and also most similar in terms of climate and soil (García del Pino \& Palomo, 1996; Campos-Herrera et al., 2007; Emelianoff et al., 2008). Steinernema feltiae and $H$. bacteriophora, the two most abundant EPN species in continental Portugal, are also considered to be the two most common species in Europe, having also been found in southern France and northern Spain (Hominick, 2002). However, conclusions regarding diversity and biogeography of EPN must be reached with some caution, since the results, in part, reflect searching effort and sampling technique rather than actual numbers and/or habitat preferences of EPN.

The major objectives of this study were to determine the indigenous species present in continental Portugal and evaluate the genetic diversity of isolates. For $H$. bacteriophora and S. feltiae, the two most abundant species found in continental Portugal, genetic diversity was assessed based on different molecular markers: ITS, D2D3 expansion region of the 28S rRNA gene and two mitochondrial genes, COXI and $c y t b$. There were no indications of a molecular and geographical intraspecific variation of either $S$. feltiae or H. bacteriophora.

According to our results, $H$. bacteriophora isolates show no differences concerning the $c y t b$ gene, ITS and D2D3 expansion region of the $28 \mathrm{~S}$ rRNA gene. Furthermore, no genetic diversity was observed among $S$. feltiae isolates using the D2D3 expansion region of the 28S rRNA gene. However, the ITS region and COXI gene revealed some genetic diversity among $S$. feltiae isolates. The diversity found among $S$. feltiae isolates using ITS and COXI sequences has no correlation with the physical and chemical parameters that characterize soil samples, nor with NUTS, soil or vegetation type.

In conclusion, this survey shows that five EPN species are known to be present in Portuguese soils. Furthermore, the occurrence of $S$. feltiae and H. bacteriophora as the two most abundant species in continental Portugal, suggests the potential role of these nematodes in natural regulation of insect populations. Further research on host ranges and characterization of these nematodes in view of possible use in biological control should be undertaken to minimize the use of chemical pesticides. 


\section{Supplementary material}

To view supplementary material for this article, please visit http://dx.doi.org/10.1017/S0022149X13000217

\section{Acknowledgements}

The authors kindly thank Ms Inácia Ferreira for technical assistance. We would also like to thank Mr José Carlos Garcia dos Santos for helping with the ArcGIS software. This communication is a portion of the $\mathrm{PhD}$ dissertation of the first author, who was supported by a doctoral scholarship from 'Fundação para a Ciência e a Tecnologia' (SFHR \BD $\backslash 22086 \backslash 2005)$. This work is funded by FEDER Funds through the Operational Programme for Competitiveness Factors-COMPETE and National Funds through FCT (Fundaçäo para a Ciência e Tecnologia) under the Strategic Project PEst-C/AGR/UI0115/2011.

\section{References}

Adams, B.J., Peat, S.M. \& Dillman, A.R. (2007) Phylogeny and evolution. pp. 693-733 in Nguyen, K.B. \& Hunt, D.J. (Eds) Entomopathogenic nematodes: systematics, phylogeny and bacterial symbionts. Nematology Monographs and Perspectives 5. Leiden, The Netherlands, Brill.

Bedding, R.A. \& Akhurst, R.J. (1975) A simple technique for the detection of insect parasitic nematodes in soil. Nematologica 21, 109-110.

Bednarek, A. (1998) The agricultural system, as a complex factor, effects the population of entomopathogenic nematodes (Rhabditida: Steinernematidae) in the soil. IOBC Bulletin 21, 155-216.

Boag, B., Nielson, R. \& Gordon, S. (1992) Distribution and prevalence of the entomopathogenic nematode Steinernema feltiae in Scotland. Annals of Applied Biology 121, 355-360.

Boemare, N. (2002) Biology, taxonomy and systematics of Photorhabdus and Xenorhabdus. pp. 35-56 in Gaugler, R. (Ed.) Entomopathogenic nematology. Wallingford, UK, CABI Publishing.

Bruck, D.J. (2004) Natural occurrence of entomopathogens in Pacific Northwest nursery soil and their virulence to the black vine weevil, Otiorhynchus sulcatus (F.) (Coleoptera: Curculionidae). Environmental Entomology 33, 1335-1343.

Burman, M., Abrahamsson, K., Ascard, J., Sjoberg, A. \& Erikson, B. (1986) Distribution of insect parasitic nematodes in Sweden. p. 312 in Samson, R.A., Vlak, J.M. \& Peters, D. (Eds) Fundamentals and applied aspects of invertebrate pathology. Wageningen, The Netherlands, Foundation of the 4th International Colloquium on Invertebrate Pathology.

Caetano, M., Araújo, A., Nunes, A., Nunes, V. \& Pereira, M. (2009) Accuracy assessment of the CORINE Land Cover 2006 map of Continental Portugal. 47 pp. Lisbon, Relatório Técnico, Instituto Geográfico Português.

Campos-Herrera, R., Escuer, M., Labrador, S., Robertson, L., Barrios, L. \& Gutiérrez, C. (2007) Distribution of the entomopathogenic nematodes from La Rioja (Northern Spain). Journal of Invertebrate Pathology 95, 125-139.
Campos-Herrera, R., Johnson, E.G., El-Borai, F.E., Stuart, R.J., Graham, J.H. \& Duncan, L.W. (2011) Long-term stability of entomopathogenic nematode spatial patterns measured by sentinel insects and realtime PCR assays. Annals of Applied Biology 158, 55-68.

De Doucet, M.M.A. \& Gabarra, R. (1994) On the occurrence of Steinernema glasseri (Steiner, 1929) (Steinernematidae) and Heterorhabditis bacteriophora Poinar, 1976 (Heterorhabditidae) in Catalogne, Spain. Fundamental Applied Nematology 17, 441-443.

Downes, M.J. \& Griffin, C.T. (1991) Recovery of heterorhabditid nematodes from Irish and Scottish soils. pp. 216-218 in Smits, P.H. (Ed.) Proceedings of the Third European Meeting Microbial Control of Pests. IOBC/WPRS Bulletin, Wageningen, The Netherlands.

Edgington, S., Buddie, A.G., Moore, D., France, A., Merino, L., Tymo, L.M. \& Hunt, D.J. (2010) Diversity and distribution of entomopathogenic nematodes in Chile. Nematology 12, 915-928.

Ehlers, R.U., Deseo, K.V. \& Stackebrandt, E. (1991) Identification of Steinernema spp. from Italian and German soils. Nematologica 37, 360-366.

El-Borai, F., Stuart, R.J., Campos-Herrera, R., Pathak, E. \& Duncan, L.W. (2012) Entomopathogenic nematodes, root weevil larvae, and dynamic interactions among soil texture, plant growth, herbivory, and predation. Journal of Invertebrate Pathology 109, 134-142.

Emelianoff, V., Le Brun, N., Pages, S., Stock, P., Tailliez, P., Moulia, C. \& Sicard, M. (2008) Isolation and identification of entomopathogenic nematodes and their symbiotic bacteria from Herault and Gard (Southern France). Journal of Invertebrate Pathology 98, 211-217.

FAO, (2006) World reference base for soil resources 2006. A framework for international classification, correlation and communication. 145 pp. Rome, FAO.

Felsenstein, J. (1985) Confidence limits on phylogenies: An approach using the bootstrap. Evolution 34, 783-791.

García del Pino, F. (1994) Los nematodos entomopatógenos (Rhabditida: Steinernematidae y Heterorhabditidae) presentes en Cataluna y su utilizacion para el control biológico de insectos. PhD thesis, Universidad Autónoma de Barcelona, Barcelona..

García del Pino, F. (2005) Natural occurrence of entomopathogenic nematodes in Spain. MC-Meeting and Working Group 4th Meeting: Natural occurrence and evolution of entomopathogenic nematodes and Management Committee Meeting, Ceske Budejovice, The Czech Republic, 14-17 January.

García del Pino, F. \& Palomo, A. (1996) Natural occurrence of entomopathogenic nematodes (Rhabditida: Steinernematidae and Heterorhabditidae) in Spanish soils. Journal of Invertebrate Pathology 68, 84-90.

Georgis, R., Koppenhöfer, A.M., Lacey, L.A., Bélair, G., Duncan, L.M., Grewal, P.S., Samish, M., Tan, L., Torr, P. \& van Tol, R.W.H.M. (2006) Successes and failures in the use of parasitic nematodes for pest control. Biological Control 38, 103-123.

Glazer, I., Liran, N. \& Steinberger, Y. (1991) A survey of entomopathogenic nematodes (Rhabditida) in the Negev desert. Phytoparasitica 19, 291-300. 
Griffin, C.T., Moore, J.F. \& Downes, M.J. (1991) Occurrence of insect parasitic nematodes (Steinernematidae, Heterorhabditidae) in the Republic of Ireland. Nematologica 37, 92-100.

Gwynn, R.L. \& Richardson, P.N. (1996) Incidence of entomopathogenic nematodes in soil samples collected from Scotland, England and Wales. Fundamental and Applied Nematology 19, 427-431.

Hall, T.A. (1999) BioEdit: a user-friendly biological sequences alignment editor and analysis program for Windows 95/98/NT. Nucleic Acids Research 41, 95-98.

Hasegawa, M., Kishino, H. \& Yano, T.A. (1985) Dating of the human shape splitting by a molecular clock of mitochondrial DNA. Journal of Molecular Evolution 22, 160-174.

Hazir, S., Keskin, N., Stock, S.P., Kaya, H. \& Özcan, S. (2003) Diversity and distribution of entomopathogenic nematodes (Rhabditida: Steinernematidae and Heterorhabditidae) in Turkey. Biodiversity and Conservation 12, 375-386.

Hominick, W.M. (2002) Biogeography. pp. 115-143 in Gaugler, R. (Ed.) Entomopathogenic nematology. Wallingford, UK, CABI Publishing.

Hominick, W.M. \& Briscoe, B.R. (1990) Occurrence of entomopathogenic nematodes (Rhabditida: Steinernematidae and Heterorhabditidae) in British soils. Parasitology 100, 295-302.

Hominick, W.M., Reid, A.P., Bohan, D.A. \& Briscoe, B.R. (1996) Entomopathogenic nematodes: biodiversity, geographical distribution and the Convention on Biological Diversity. Biocontrol Science and Technology 6, 317-331.

Hozzank, A., Wegensteiner, R., Waitzbauer, W., Burnell, A., Mráček, Z. \& Zimmermann, G. (2003) Investigations on the occurrence of entomopathogenic fungi and entomoparasitic nematodes in soils from lower Austria. Bulletin OILB/SROP 26, 77-80.

Iraki, N., Salah, N., Sansour, M.A., Segal, D., Glazer, I., Johnigk, S.A., Hussei, M.A. \& Ehlers, R.U. (2003) Isolation and characterization of two entomopathogenic nematode strains, Heterorhabditis indica (Nematoda, Rhabditida), from the West Bank, Palestinian Territories. Journal of Applied Entomology 124, 375-380.

Ishibashi, N. (2002) Behaviour of entomopathogenic nematodes. pp. 511-520 in Lee, D.L. (Ed.) The biology of nematodes. London, Taylor \& Francis.

Ivanova, T.I., Danilov, L. \& Ivakhnenko, O.A. (2000) Distribution of entomopathogenic nematodes of the families Steinernematidae and Heterorhabditidae in Russia and their morphological characteristics. Parazitologiya 34, 323-334.

Joyce, S.A., Burnell, A.M. \& Powers, T.O. (1994) Characterisation of Heterorhabditis isolates by PCR amplification of segments of mtDNA and rDNA gene. Journal of Nematology 26, 260-270.

Kary, N.E., Niknam, G., Griffin, C.T., Mohammadi, S.A. \& Moghaddam, M. (2009) A survey of entomopathogenic nematodes of the families Steinernematidae and Heterorhabditidae (Nematoda: Rhabditida) in the north-west of Iran. Nematology 11, 107-116.

Kaya, H.K. \& Gaugler, R. (1993) Entomopathogenic nematodes. Annual Review of Entomology 38, 181-206.
Kaya, H.K. \& Stock, S.P. (1997) Techniques in insect nematology. pp. 281-324 in Lacey, L.A. (Ed.) Manual of techniques in insect pathology. London, Academic Press.

Kepenekci, I. (2002) Entomopathogenic nematodes (Rhabditida) in the Mediterranean region of Turkey. Nematologia Mediterranea 30, 13-15.

Khatri-Chhetri, H.B., Waeyenberge, L., Spiridonov, S., Manandhar, H.K. \& Moens, M. (2010) Two new species of Steinernema Travassos, 1927 with short infective juveniles from Nepal. Russian Journal of Nematology 19, 53-74.

Kimura, M. (1980) A simple method for estimating evolutionary rate of base substitutions through comparative studies of nucleotide sequences. Journal of Molecular Evolution 16, 111-120.

Köppen, W. \& Geiger, R. (1928) Klimate der Erde. Gotha, Verlag Justus Perthes (wall-map $150 \mathrm{~cm} \times 200 \mathrm{~cm}$ ).

Koppenhöfer, A.M. (2000) Nematodes. pp. 283-301 in Lacey, L.A. \& Kaya, H.K. (Eds) Field manual of techniques in invertebrate pathology. Dordrecht, The Netherlands, Kluwer.

Liu, J. \& Berry, R.E. (1996) Steinernema oregonensis n. sp. (Rhabditida: Steinernematidae) from Oregon, USA. Fundamental and Applied Nematology 19, 375-380.

Ma, J., Shulong, C., Zou, Y., Xiuhua, L., Richou, H., De Clercq, P. \& Moean, M. (2010) Natural occurrence of entomopathogenic nematodes in North China. Russian Journal of Nematology 18, 117-126.

Menti, H., Wright, D.J. \& Perry, R.N. (1997) Desiccation survival of populations of nematodes Steinernema feltiae and Heterorhabditis megidis from Greece and the UK. Journal of Helminthology 71, 41-46.

Midituri, J.S., Waeyenberge, L. \& Moens, M. (1997) Natural distribution of entomopathogenic nematodes (Heterorhabditidae and Steinernematidae) in Belgian soils. Russian Journal of Nematology 5, 55-65.

Mráček, Z. (1980) The use of 'Galleria traps' for obtaining nematode parasites of insects in Czechoslovakia (Lepidoptera: Nematoda, Steinernematidae). Acta Entomologica Bohemoslovaca 77, 378-382.

Mráček, Z. \& Becvár, S. (2000) Insect aggregations and entomopathogenic nematode occurrence. Nematology 2, 297-301.

Mráček, Z., Bečvár, S. \& Kindlmann, P. (1999) Survey of entomopathogenic nematodes from the families Steinernematidae and Heterorhabditidae (Nematoda: Rhabditida) in the Czech Republic. Folia Parasitologica 46, 145-148.

Mráček, Z., Bečvár, S., Kindlmann, P. \& Jersáková, J. (2005) Habitat preference for entomopathogenic nematodes, their insect hosts and new faunistic records for the Czech Republic. Biological Control 34, 27-37.

Nadler, S.A., Bolotin, E. \& Stock, S.P. (2006) Phylogenetic relationships of Steinernema Travassos, 1927 (Nematoda: Cephalobine: Steinernematidae) based on nuclear, mitochondrial and morphological data. Systematic Parasitology 63, 161-181.

Nguyen, K.B. \& Hunt, D. (2007) Entomopathogenic nematodes: Systematics, phylogeny and bacterial symbionts. 816 pp. Leiden, E.J. Brill.

Nguyen, K.B., Maruniak, J. \& Adams, B.J. (2001) The diagnostic and phylogenetic utility of the rDNA 
internal transcribed spacer sequences of Steinernema. Journal of Nematology 33, 73-82.

Nielsen, O. \& Philipsen, H. (2003) Danish surveys on insects naturally infected with entomopathogenic nematodes. Bulletin OILB/SROP 26, 131-136.

Püza, V. \& Mráček, Z. (2005) Seasonal dynamics of entomopathogenic nematodes of the genera Steinernema and Heterorhabditis as a response to abiotic factors and abundance of insect hosts. Journal of Invertebrate Pathology 89, 116-122.

Reid, A.P., Hominick, W.M. \& Briscoe, B.R. (1997) Molecular taxonomy and phylogeny of entomopathogenic nematode species (Rhabditida: Steinernematidae) by RFLP analysis of ITS region of the ribosomal DNA repeat unit. Systematic Parasitology 37, 187-193.

Rosa, J.S. \& Simões, N. (2004) Evaluation of twenty-eight strains of Heterorhabditis bacteriophora isolated in Azores for biocontrol of the armyworm, Pseudaletia unipuncta (Lepidoptera: Noctuidae). Biological Control 29, 409-417.

Rosa, J.S., Bonifassi, E., Amaral, J., Lacey, L.A., Simões, N. \& Laumond, C. (2000) Natural occurrence of entomopathogenic nematodes (Rhabditida: Steinernema, Heterorhabditis) in Azores. Journal of Nematology $32,215-222$.

Saitou, N. \& Nei, M. (1987) The neighbor-joining method: a new method for reconstructing phylogenetic trees. Molecular Biology and Evolution 4, 406-425.

Shamseldean, M.M. \& Abd-Elgawad, M.M. (1994) Natural occurrence of insect pathogenic nematodes (Rhabditida: Heterorhabditidae) in Egyptian soils. Afro-Asian Journal of Nematology 4, 151-154.

Shishiniova, M., Budurova, L. \& Gradinarov, D. (2000) Entomopathogenic nematodes from Steinernematidae and Heterorhabditidae (Nematoda: Rhabditida) in Bulgaria. Bulletin OILB/SROP 23, 75-78.

Simões, N., Laumond, C. \& Bonifassi, E. (1994) Effectiveness of Steinernema spp. and Heterorhabditis bacteriophora against Popillia japonica in Azores. Journal of Nematology 25, 480-485.

Spiridonov, S., Krasomil-Osterfeld, K. \& Moens, M. (2004) Steinernema jollieti sp. n. (Rhabditida: Steinernematidae), a new entomopathogenic nematode from the American Midwest. Russian Journal of Nematology 12, 85-95.

Steiner, W. (1996) Distribution of entomopathogenic nematodes in the Swiss Alps. Review Suisse Zoology 103, 439-452.

Stock, S.P. (2009) Molecular approaches and the taxonomy of insect-parasitic and pathogenic nematodes. pp. 71-100 in Stock, S.P., Vandenburg, J., Glazer, I. \& Boemare, N. (Eds) Insect pathogens: molecular approaches and techniques. Wallingford, Oxon, UK, CAB International Press.

Stock, S.P., Campbell, J.F. \& Nadler, S.A. (2001) Phylogeny of Steinernema Travassos, 1927 (Cephalobina:
Steinernematidae) inferred from ribosomal DNA sequences and morphological characters. Journal of Parasitology 87, 877-889.

Stock, S.P., Al Banna, L., Darwish, R. \& Katbeh, A. (2008) Diversity and distribution of entomopathogenic nematodes (Nematoda: Steinernematidae, Heterorhabditidae) and their bacterial symbionts (c-Proteobacteria: Enterobacteriaceae) in Jordan. Journal of Invertebrate Pathology 98, 228-234.

Sturhan, D. \& Liskova, M. (1999) Occurrence and distribution of entomopathogenic nematodes in the Slovak Republic. Nematology 1, 273-277.

Sturhan, D. \& Ruess, L. (1999) An undescribed Steinernema sp. (Nematoda: Steimernematidae) from Germany and the Scandinavian Subartic. Russian Journal of Nematology 7, 43-47.

Tamura, K. (1992) Estimation of the number of nucleotide substitutions when there are strong transition-transversion and $\mathrm{G}+\mathrm{C}$-content biases. Molecular Biology and Evolution 9, 678-687.

Tamura, K. \& Nei, M. (1993) Estimation of the number of nucleotide substitutions in the control region of mitochondrial DNA in humans and chimpanzees. Molecular Biology and Evolution 10, 512-526.

Tamura, K., Peterson, D., Peterson, N., Stecher, G., Nei, M. \& Kumar, S. (2011) MEGA5: Molecular evolutionary genetics analysis using maximum likelihood, evolutionary distance, and maximum parsimony methods. Molecular Biology and Evolution 28, 2731-2739.

Tarasco, E. \& Triggiani, O. (1997) Survey of Steinernema and Heterorhabditis (Rhabditida: Nematoda) in southern Italian soils. Entomologica 31, 117-123.

Triggiani, O. \& Tarasco, E. (2000) Occurrence of entomopathogenic nematodes (Rhabditida: Steinernematidae and Heterorhabditidae) in pine and oak woods in Southern Italy. Entomologica 34, 23-32.

Valadas, V., Boyle, S., Vieira, P., Kakouli-Duarte, T. \& Mota, M. (2007) First report of an entomopathogenic nematode from continental Portugal. Helminthologia 44, 226-229.

Valadas, V., Vieira, P., Oliveira, S. \& Mota, M. (2009) First report of the genus Heterorhabditis (Nematoda: Heterorhabditidae) from continental Portugal. Helminthologia 46, 45-48.

Valadas, V., Mráček, Z., Oliveira, S. \& Mota, M. (2011) Three species of entomopathogenic nematodes of the family Steinernematidae (Nematoda: Rhabditida) new to Continental Portugal. Nematologia Mediterranea 39, $169-178$.

Vänninen, I., Husberg, G.B. \& Hokkanen, H.M.T. (1989) Occurrence of entomopathogenic fungi and entomoparasitic nematodes in cultivated soils in Finland. Acta Entomologica Fennica 53, 65-71.

White, G.F. (1927) A method for obtaining infective juveniles from cultures. Science 66, 302-303. 